\title{
Infection Prevention in the Era of COVID-19: 2021 Basic Procedure Review
}

\author{
Barbara J. Jara, CNMT \\ Nuclear Diagnostic Products, Pharmalogic, Lansdowne, Pennsylvania
}

CE credit: For CE credit, you can access the test for this article, as well as additional JNMT CE tests, online at https://www.snmmilearningcenter.org. Complete the test online no later than June 2024. Your online test will be scored immediately. You may make 3 attempts to pass the test and must answer $80 \%$ of the questions correctly to receive $1.0 \mathrm{CEH}$ (Continuing Education Hour) credit. SNMMI members will have their CEH credit added to their VOICE transcript automatically; nonmembers will be able to print out a CE certificate upon successfully completing the test. The online test is free to SNMMI members; nonmembers must pay $\$ 15.00$ by credit card when logging onto the website to take the test.

Infection prevention and control practices represent a vital behavioral skill set, especially in the era of COVID-19. Standard precautions, correct use of personal protective equipment, proper hand hygiene, and appropriate cleaning and disinfecting are necessary to prevent health-care-acquired infections in care facilities.

Key Words: COVID-19; standard precautions; personal protective equipment; hand hygiene; health-care-acquired infections

J Nucl Med Technol 2021; 49:126-131

DOI: $10.2967 /$ jnmt.121.262281

C oronavirus disease 2019 (COVID-19) has brought infection prevention and control into the spotlight as healthcare facilities implement specific infection prevention and control procedures to protect staff and patients from the novel virus. COVID-19 proved that emerging infectious diseases pose an ever-present challenge for care providers. To achieve success, infection prevention practices must be coordinated throughout the care continuum and must be inherent behavior. Many of the fundamental infection control practices used in everyday practice are equally important during the pandemic. Therefore, technologists now have an opportune time to review and brush up on best practices for infection prevention and control. This article will provide a basic review of the current recommendations on infection prevention for hospitals, ambulatory care centers, and outpatient clinics.

\section{HEALTH-CARE-ACQUIRED INFECTIONS (HAIS)}

HAIs, also referred to as nosocomial infections, are infections acquired by patients when receiving care in a healthcare facility such as a hospital, ambulatory care center, outpatient clinic, or doctor or dental office. Over the last decade, infection prevention and control have been at the

\footnotetext{
Received Mar. 10, 2021; revision accepted Apr. 15, 2021.

For correspondence or reprints, contact Barbara J. Jara (jarab1056@yahoo. com).

COPYRIGHT (C) 2021 by the Society of Nuclear Medicine and Molecular Imaging.
}

forefront of the battle to improve health-care quality, as morbidity and mortality statistics are concerning and the economic impact is appalling. The Centers for Disease Control and Prevention (CDC) 2015 HAI Prevalence Survey data revealed that approximately 1 in 31 hospital patients developed at least 1 HAI, resulting in 687,000 HAIs and 72,000 deaths (1). Robust infection prevention education focusing on implementing standard precautions, increased hand hygiene compliance, and proper use of personal protective equipment (PPE) resulted in a 16\% reduction in HAIs in 2015 compared with 2011.

Specifically, health-care facilities have worked diligently to arrest central line-associated bloodstream infections, vancomycin-resistant enterococci, Clostridium difficile, methicillin-resistant Staphylococcus aureus, and surgical site infections. The CDC's National Healthcare Safety Network, the most widely used HAI tracking system, provides data to identify problem areas and measure progress in infection prevention efforts to eliminate HAIs (2). The Healthcare Infection Control Practices Advisory Committee, a federal advisory committee, guides both the Department of Health and Human Services and the $\mathrm{CDC}$ on infection control practices and strategies for the surveillance, prevention, and control of HAIs, antimicrobial resistance, and adverse events in U.S. health-care settings (3).

\section{TYPES OF PRECAUTIONS}

\section{Transmission-Based Precautions}

Transmission-based precautions, used in concert with the standard precautions described below, are implemented when patient infection or colonization is suspected (4). The intent is to isolate and contain the contagion. Transmission-based precautions include placement of the patient in a single room to isolate transmission. Transportation of the patient out of the room should be limited, and the patient should wear a mask when being transported or receiving care. The required PPE for staff includes gown, gloves, and an N95 filtering facepiece respirator (FFR) to limit aerosol transmission risk. Staff and visitor contact with the patient should be limited.

Direct transmission occurs when microbes transfer to a person directly from an infected person instead of from a 
contaminated intermediate object or person. Blood, body fluids, breaks in the skin, and uncovered sneezing are examples of direct transmission. Droplet transmission results from respiratory droplets emitted from sneezing, coughing, speaking, or respiratory suction procedures. Respiratory droplets travel a short distance and necessitate facial protection.

Indirect transmission involves transfer of the infectious agent through a contaminated intermediate object or person. It is difficult to determine how indirect transmission occurs, but evidence suggests that contaminated hands of healthcare workers, as well as patient-care devices such as intravenous pumps, blood pressure cuffs, and instruments, contribute to transmission.

Airborne transmission involves airborne droplet nuclei or small particles that remain in the air and are dispersed over long distances by air currents. Measles and chickenpox are examples of droplet-nuclei airborne transmission (Fig. 1).

\section{Standard Precautions}

Universal precautions were introduced to health-care workers in 1985 in response to the widespread growth of HIV and the risk of transmission posed by exposure to infected blood from needle sticks. In the 1990s, experts recognized that body fluids also presented a risk for transmission of infectious disease. In response, practices to isolate body substances were proposed. Because a period of confusion followed, enhanced precautions, termed standard precautions, were introduced to reduce the risk of transmission of blood-borne and other pathogens in health-care facilities (5). Standard precautions assume that all blood and body fluids from any patient could be infectious. Standard precautions include use of hand

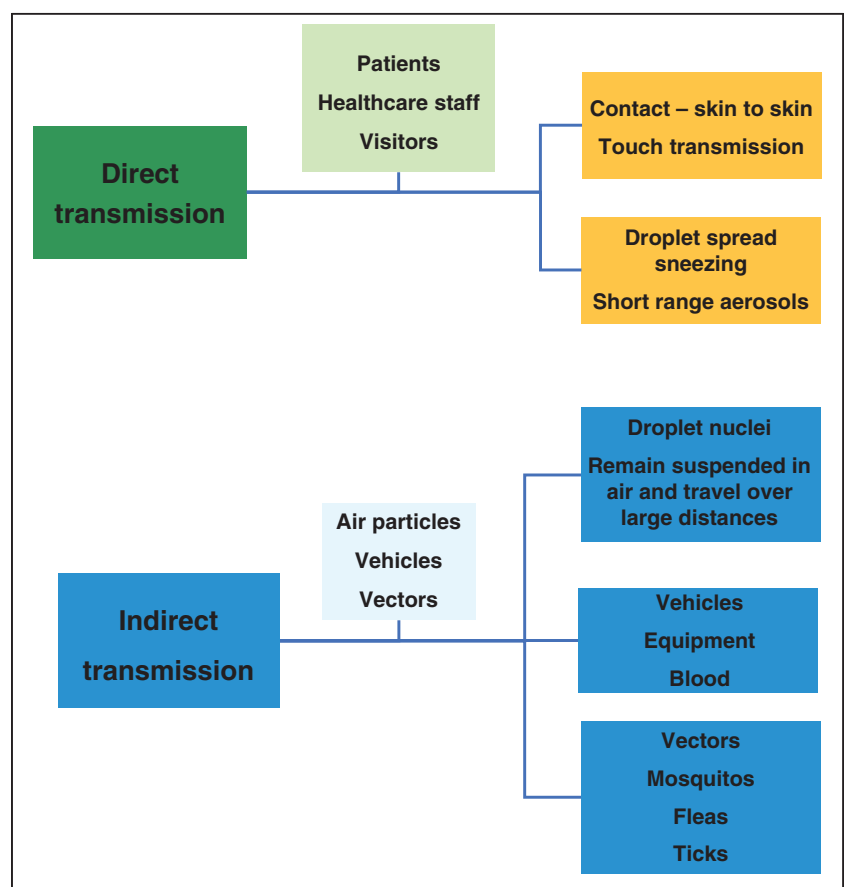

FIGURE 1. Modes of pathogen transmission. Microbe transmission occurs via 2 primary pathways: direct and indirect. hygiene along with gloves, gowns, masks, eye protection, and face shields.

Hand Hygiene. It is now common knowledge that hand hygiene is a critical component for reducing the spread of pathogens, as hands can be a primary vector for contact transmission of infections. Good hand hygiene practice includes washing with soap and water for $20 \mathrm{~s}$ when hands are visibly soiled, before eating, after using the restroom, and after sneezing. Alcohol-based hand rubs, which have greatly improved hand hygiene compliance, containing $60 \%-95 \%$ alcohol are preferred when hands are not visibly soiled. The recommended procedure suggests using a dimesized drop of alcohol-based hand rub placed in the palm of one hand and then rubbed between both hands, covering the entire surface of the hands and fingers until the hands are dry. Usually, the process takes about $15 \mathrm{~s}$. Alcohol-based sanitizer can inactivate COVID-19 (6).

$P P E$. The degree of PPE required is determined by the level of clinical interaction with the patient and the risk of transmission (7). Several methods for properly donning and doffing equipment are acceptable; health-care workers should follow their facility's requirements (Table 1). Health-care workers must don PPE before entering a patient's room or interacting with a patient to provide care or diagnostic services.

\section{FACE MASKS}

\section{Face Masks Versus N95 FFRs}

Health-care workers should understand the difference between a face mask and an N95 FFR. A facemask fits loosely on the face, protecting against large airborne particles, splashes, or sprays of body fluids. It protects the patient from the wearer's respiratory emissions. It does not provide the same level of protection from inhaling small airborne particles as N95 FFRs. According to title 42 of the Code of Federal Regulations, part 84, N95 FFRs must be compliant with the National Institute for Occupational Safety and Health standards and capable of filtering 95\% of large and small airborne particles to reduce exposure to both aerosols and droplets $(8)$. They cover the face and require prefitting to ensure a tight seal around the nose, mouth, and chin. Usually, face masks and N95 FFRs are discarded after one use. However, the COVID-19 virus significantly strained PPE supplies, especially face masks and N95 FFRs. The CDC, National Institutes of Health, and several academic institutions developed processes and guidelines for reuse and decontamination of N95 FFRs.

\section{Mask Reuse}

During the intense periods of infection during the COVID-19 pandemic, health-care institutions faced severe equipment shortages and were forced to conserve PPE. In fact, most were at the contingency (expected shortages) and crisis (known shortages) capacities (8). In response, contingency strategies based on the current calculated PPE consumption rate, or burn rate, were developed. 
TABLE 1

CDC's PPE Donning and Doffing Recommendations (12)

\begin{tabular}{|c|c|}
\hline Parameter & Sequence \\
\hline \multirow[t]{6}{*}{ Donning } & Select appropriate PPE for patient interaction \\
\hline & $\begin{array}{l}\text { Perform hand hygiene using } 60 \%-95 \% \\
\text { alcohol-based hand rub }\end{array}$ \\
\hline & $\begin{array}{l}\text { Put on isolation gown and tie all gown ties; } \\
\text { put on NIOSH-approved N95 FFR or face } \\
\text { mask if N95 is not available }\end{array}$ \\
\hline & Put on face shield or goggles \\
\hline & Put on gloves \\
\hline & Enter patient room or initiate care procedure \\
\hline \multirow[t]{6}{*}{ Doffing } & Remove gloves \\
\hline & Remove gown \\
\hline & $\begin{array}{l}\text { Exit patient room or care procedure area; } \\
\text { perform hand hygiene using } 60 \%-95 \% \\
\text { alcohol-based hand rub }\end{array}$ \\
\hline & Remove face shield or goggles \\
\hline & Remove and discard face mask or FFR \\
\hline & $\begin{array}{l}\text { Perform hand hygiene after removing FFR/ } \\
\text { face mask and before putting on again if } \\
\text { facility practicing equipment reuses }\end{array}$ \\
\hline
\end{tabular}

$\mathrm{NIOSH}=$ National Institute for Occupational Safety and Health.

N95 FFR reuse depends on a facility's supply and surge capacity status. Limited reuse is the practice of using the same N95 FFR for multiple encounters with patients, but it is removed (doffed) after each encounter. Extended reuse is when the same FFR is worn continuously for encounters with multiple patients. The number of times an N95 FFR can be reused depends on the fit, elastic strap integrity, filtration performance, contamination, and damage. The CDC recommends 5 uses per mask as long as the mask fits tightly, ensuring proper performance. Health-care workers should follow their facility's policy regarding mask reuse.

\section{Decontamination of N95 FFRs}

On March 29, 2020, the U.S. Food and Drug Administration issued the first emergency-use authorization for a procedure to decontaminate N95 FFRs. Several subsequent emergency-use authorizations have since been published. Effective decontamination of N95 FFRs reduces the pathogen burden, does not alter the fit or filtration performance, and presents no residual chemical hazard. As of April 2020, ultraviolet germicidal irradiation, vaporous hydrogen peroxide, and moist heat have shown the most promise as potential methods to decontaminate N95 FFRs (9). Many of the decontamination processes developed, tested, and validated are specific for the brand of N95 FFR.

Specific to COVID-19, the National Institutes of Health scientists investigated decontamination procedures for small sections of N95 filter fabric exposed to severe acute respiratory syndrome coronavirus 2 , the virus that causes COVID19. They used vaporous hydrogen peroxide, ultraviolet light, $70^{\circ} \mathrm{C}$ dry heat, and $70 \%$ ethanol spray $(10,11)$. The scientists concluded that all methods successfully eliminated detectable viable virus. However, the ethanol spray damaged the FFR's fit and seal after 2 decontamination cycles and is therefore not recommended.

The investigators also concluded that the vaporous hydrogen peroxide decontamination process was very effective, as no virus was detected after only a 10 -min treatment. The fit integrity was maintained, and the N95 FFR could be decontaminated and reused up to 3 times. Ultraviolet germicidal irradiation and dry heat were acceptable decontamination procedures but required at least $60 \mathrm{~min}$. They are recommended for 2 reuse and decontamination cycles (11). All decontamination treatments must be conducted for a sufficient time to ensure adequate reduction of the virus concentration. The degree of required reduction depends on the degree of initial virus contamination. According to the Food and Drug Administration, CDC, and Occupational Safety and Health Administration FFR guidelines, the fit, seal, and functional integrity of decontaminated N95 FFRs should be evaluated.

\section{GLOVES}

Hand hygiene with soap and water for $20 \mathrm{~s}$ or $60 \%-95 \%$ alcohol-based hand rub should be performed before donning and after removal of gloves. Disposable gloves should always be discarded after a single task or patient encounter. The correct method requires removing the gloves carefully by grasping the cuff and gently pulling the glove inside itself as it slides off the hand. The process is repeated for the other hand, and both gloves are discarded.

The CDC does not recommend disinfection of disposable medical gloves as a standard practice, but in an extreme shortage of disposable gloves, this option may be considered to extend glove use (12). In the event of a glove supply crisis, gloves must be sanitized between patients within a cohort (a group of individuals with a common disease, treatment, or other similar traits) to prevent cross-contamination of microbes from patient to patient (Table 2). In the event of a glove shortage, gloves should always be discarded when visibly soiled, damaged, or after $4 \mathrm{~h}$ of continuous use.

Glove reuse and sanitation should be initiated only at the directive of the health-care facility administration and performed in accordance with the established policies and procedures. Sanitized gloves should be evaluated for signs of damage such as tears, holes, and rips (12). Material degradation assessments of whether gloves are brittle, stiff, or tacky should be performed, and if damage or degradation is noted, the gloves must be discarded. Glove reuse and sanitization should be terminated immediately when an adequate glove supply materializes.

\section{CLEANING AND DISINFECTING}

The policies, procedures, and practice of cleaning and disinfecting health-care facilities are complicated because of the diverse nature of care procedures. For example, surgical suite cleaning and disinfection procedures are very different from those for an imaging department, yet both require proper performance to protect patients and staff from pathogens. 
TABLE 2

Methods for Sanitizing Gloved Hands for Extended Use of Disposable Medical Gloves $(12,19)$

\begin{tabular}{|c|c|c|}
\hline Method & Recommendation & Notes \\
\hline $\begin{array}{l}\text { Alcohol-based } \\
\text { hand sanitizer }\end{array}$ & $\begin{array}{l}\text { Preferred method when gloves (latex or nitrile) are } \\
\text { not soiled }\end{array}$ & Can be disinfected up to 6 times \\
\hline Soap and water & Best use with long cuffed gloves & $\begin{array}{l}\text { Can be cleaned with soap and water } \\
\text { up to } 10 \text { times }\end{array}$ \\
\hline $\begin{array}{l}\text { Diluted bleach } \\
\text { solution }\end{array}$ & $\begin{array}{l}\text { Use } 10 \%-13 \% \text { bleach solution; dip gloved hands in } \\
\text { solution for } 5 \mathrm{~s} \text {; allow solution to remain for } 1 \mathrm{~min} \text {; } \\
\text { rinse with water and dry with clean cloth }\end{array}$ & $\begin{array}{l}\text { Can be disinfected in bleach solution } \\
\text { up to } 10 \text { times }\end{array}$ \\
\hline
\end{tabular}

https://www.cdc.gov/coronavirus/2019-ncov/hcp/ppe-strategy/gloves.html

TABLE 3

Low-Level Disinfection for Noncritical Equipment and Surfaces (Exposure Time $\geq 1$ Minute) $(20,21)$

\begin{tabular}{lc}
\hline Germicide & Use concentration \\
\hline $\begin{array}{l}\text { Ethyl or isopropyl } \\
\text { alcohol }\end{array}$ & $70 \%-90 \%$ \\
Chlorine & 100 ppm (1:500 dilution) \\
Phenolic & Manufacturer's recommendation \\
lodophor & Manufacturer's recommendation \\
$\begin{array}{l}\text { Quaternary ammonium } \\
\text { Improved hydrogen } \\
\text { peroxide }\end{array}$ & Manufacturer's recommendation \\
\hline
\end{tabular}

Scientific evidence consistently demonstrates that contaminated environmental surfaces and noncritical items for patient care play a critical role in HAI transmission (13). Noncritical items are objects that come into contact with intact skin when the sterility of the skin contact is not critical. For example, bed rails, tray tables, blood pressure cuffs, infusion pumps, and exam tables are common noncritical items that potentially contribute to secondary transmission by contaminating health-care workers' hands and other medical equipment. According to Spaulding's classification scheme, noncritical equipment requires low-level disinfection (14).

All health-care facilities must use disinfectants registered with the U.S. Environmental Protection Agency. The label on these disinfectants and the material safety data sheet specify the length of contact time (kill time) necessary to inactivate one or more microorganisms completely. Cleaning and disinfecting with 1-step agents containing detergentdisinfection components require no precleaning unless significant contamination or a spill exists.

Currently, Environmental Protection Agency-registered disinfectants are available with contact times of 1-4 min. Rapid kill times increase confidence in the complete killing of the most common HAI pathogens before the disinfecting solution dries or is removed and before patients or staff retouch the surface (15). The efficacy of wipes, sprays, and solution dilution recommendations are determined according to methods developed by the Association of Official Analytic Chemists.

\section{Disinfectant Wipes}

The CDC recommends applying a low-level agent (i.e., quaternary ammonium compounds, alcohols, or chlorine) to disinfect noncritical surfaces and equipment and allowing the agent to dry for $1 \mathrm{~min}$ (16). Several scientific studies evaluating microbial reduction based on wet time, contact time, and dry time demonstrated significant microbial reduction with contact times of 30-60 s $(13,15,17)$. Disposable wipes should stay sufficiently wet for $1-2 \mathrm{~min}$ to achieve the Environmental Protection Agency-required contact time of at least $1 \mathrm{~min}$ (Table 3 ). Wipe size and surface coverage depend on the size of the area to be disinfected. When the wipe is visibly soiled or no longer wets the surface, the wipe must be discarded and replaced. Never redip a wipe into the container of presaturated wipes, and always close the container top to prevent wipes from drying out (14). Facilities mandate which disinfectant products to use and the frequency of product rotation to maintain efficacy. If the facility uses spray bottle solutions, the bottle must be dated and replaced every 6 mo.

\section{Cleaning and Disinfection Importance}

Infection control and prevention are ever changing, as are the pathogens that health-care facilities face daily. It is well documented in the scientific literature that microbial pathogens survive on objects and surfaces for varying times (Table 4).

Although cleaning and disinfecting are mandatory and effective in reducing HAIs, many environmental surfaces and objects in patient rooms are often inadequately cleaned and decontaminated (18). C. difficile, methicillin-resistant S. aureus, and vancomycin-resistant enterococci are common pathogens causing transmission concerns in hospitals. Thus, patient-care areas require enhanced disinfection after discharge of a patient.

Effective surface disinfection has 2 components: the disinfectant and the way the procedure is performed. Together, they are commonly referred to as the practice and include thorough application of disinfectant to all touchable surfaces (15). The practice should be mastered and become second nature as an integral step in daily patient-care duties. Standardization and proper training by an environmental services department or infection prevention and control personnel should focus on product selection and contact time. 
TABLE 4

Survival Times for Some of the Most Common HAls, Viruses, and COVID-19

\begin{tabular}{|c|c|c|c|}
\hline \multicolumn{2}{|c|}{ Pathogen survival on dry, inanimate surfaces (22) } & \multicolumn{2}{|c|}{ COVID-19 survival on surfaces* ${ }^{*}(23)$} \\
\hline Pathogen & Survival time & Surface & Survival time \\
\hline C. difficile (spores) & $>5 \mathrm{mo}$ & Glass & $5 \mathrm{~d}$ \\
\hline Escherichia coli & $1.5 \mathrm{~h}-1.3 \mathrm{y}$ & Wood & $4 \mathrm{~d}$ \\
\hline $\begin{array}{l}\text { Vancomycin-resistant or } \\
\text {-susceptible enterococci }\end{array}$ & $5 \mathrm{~d}-4 \mathrm{mo}$ & Plastic and stainless steel & $3 d$ \\
\hline S. aureus & $7 \mathrm{~d}-7 \mathrm{mo}$ & Cardboard & $24 \mathrm{~h}$ \\
\hline Streptococcus pneumoniae & $1-20 d$ & Copper & $4 \mathrm{~h}$ \\
\hline Hepatitis B & $2 \mathrm{~h}-60 \mathrm{~d}$ & & \\
\hline Adenovirus & $7 \mathrm{~d}-3 \mathrm{mo}$ & & \\
\hline Influenza virus & $1-2 d$ & & \\
\hline Respiratory syncytial virus & $\leq 6 \mathrm{~h}$ & & \\
\hline $\begin{array}{l}\text { Coronavirus (severe acute respiratory } \\
\text { syndrome, gastrointestinal, cold) }\end{array}$ & $3-28 d$ & & \\
\hline
\end{tabular}

*Amount of live virus decreases over time on surfaces; risk of infection from touching something that had virus on it for a few days (or even a few hours) would be less.

\begin{tabular}{|c|c|c|c|}
\hline \multicolumn{4}{|c|}{ Comparison Mechanical Decontamination Technology } \\
\hline \multicolumn{2}{|c|}{ Vaporized Hydrogen Peroxide } & \multicolumn{2}{|c|}{ UV-C Irradiation } \\
\hline Advantages & Disadvantages & Advantages & Disadvantages \\
\hline $\begin{array}{l}\text { - Reliable biocidal } \\
\text { activity against a wide } \\
\text { range of pathogens } \\
\text { - Generate a turbulent } \\
\text { aerosol } \\
\text { - Uses evaporation to } \\
\text { quickly disperse } \mathrm{H}_{2} \mathrm{O}_{2} \\
\text { vapor } \\
\text { - Concentrated micro- } \\
\text { droplets contact spaces } \\
\text { beyond the reach of } \\
\text { sprays, wipes, UV lights } \\
\text { - Useful on complex } \\
\text { equipment and furniture }\end{array}$ & $\begin{array}{l}\text { - Terminal room/area } \\
\text { disinfection; not daily } \\
\text { cleaning } \\
\text { - Patients/staff must } \\
\text { vacate the room or area } \\
\text { - Decontamination } \sim 2 \mathrm{~h} \\
\text { - Disable HVAC system } \\
\text { and seal room with tape } \\
\text { - Substantial equipment } \\
\text { cost }\end{array}$ & $\begin{array}{l}\text { - Emits UV-C } 254 \mathrm{~nm} \\
\text { wavelength to } \\
\text { decontaminate surfaces } \\
\text { - Measures UV } \\
\text { reflected from } \\
\text { surrounding surfaces to } \\
\text { calculate and deliver } \\
\text { lethal dose for } \\
\text { pathogens } \\
\text { - Rapid room } \\
\text { decontamination } \\
\text { - } 5-25 \text { min for } \\
\text { vegetative bacteria } \\
\text { - HVAC does not need } \\
\text { to be disabled }\end{array}$ & $\begin{array}{l}\text { - Terminal room/area } \\
\text { disinfection; not daily } \\
\text { cleaning } \\
\text { - Patients/staff must } \\
\text { vacate the room or area } \\
\text { - Does not remove dust } \\
\text { and stains } \\
\text { - Reduced effectiveness } \\
\text { when surfaces were not } \\
\text { in direct line of sight } \\
\text { - Substantial equipment } \\
\text { cost }\end{array}$ \\
\hline \multicolumn{4}{|c|}{$\begin{array}{l}\text { Adapted from: Role of the Environmental Surfaces in Disease Transmission: "No Touch" } \\
\text { Technologies Reduce HAls } \\
\text { https://spice.unc.edu/wp-content/uploads/2017/05/Role-of-Env-Surfaces-in-Disease-Transmission- } \\
\text { Rutala.pdf }\end{array}$} \\
\hline
\end{tabular}

FIGURE 2.

Novel no-touch or mechanical room decontamination methods represent new technology in the battle against HAIs. Data on the previously discussed vaporous hydrogen peroxide and ultraviolet germicidal irradiation systems show that they help reduce the incidence of HAIs (Fig. 2). They are recommended for room decontamination after discharge of a patient when there are contact precautions (18).

\section{INFECTION-PREVENTION PRACTICES AND GUIDELINES FOR SAFE ROUTINE IMAGING CARE}

Radiation workers are very familiar with the concept of time, distance, and shielding. These terms are also applicable in infection prevention. In response to COVID-19, the dynamics of patient flow and procedure time have changed to allow social distancing throughout a facility and the imaging lab.

Patients are now prescreened for COVID-19 risk when the appointment is scheduled and when they arrive at the facility for the procedure. Asking questions, checking body temperature, and looking for symptoms are now standard procedures. Facilities use prioritization schemes based on a patient's clinical risk and prognostic outcome to determine the urgency of the procedure. Facilities are continuously updating policies based on the current pandemic numbers and federal and state guidelines to accommodate the diagnostic needs of the patient and to coordinate care with referring physicians. 
The American College of Radiology, the Society of Nuclear Medicine and Molecular Imaging, and the American Society of Nuclear Cardiology published consensus guidelines and best practices to assist facilities in developing a care plan for patients who require imaging $(24,25)$.

\section{CONCLUSION}

Today, the world has a heightened awareness regarding infection prevention, and everyone is making an effort to contain the spread and transmission of COVID-19. Infection prevention and control practices have been evaluated, upgraded, and standardized to ensure that health-care workers know how to protect themselves, other staff members, and patients. Every health-care institution and provider must have policies and procedures for rendering care and services to asymptomatic, suspected, and confirmed COVID-19 patients.

Time to disinfect imaging rooms and noncritical equipment must now be recognized as an essential component of the patient imaging procedure. Donning and doffing PPE, disinfecting the care area, and complying with robust hand hygiene all take time and training.

The infection prevention and control skills we learn and practice are dynamic and will continue to change to address microbe mutations and emerging pathogens such as COVID-19. Health-care workers must master infection prevention procedures, which must be an integral part of the patient-care routine.

\section{DISCLOSURE}

No potential conflict of interest relevant to this article was reported.

\section{REFERENCES}

1. Data portal. Centers for Disease Control and Prevention website. https://www.cdc. gov/hai/data/portal/index.html. Updated November 20, 2021. Accessed April 22, 2021.

2. About NHSN. Centers for Disease Control and Prevention website. https://www. cdc.gov/nhsn/about-nhsn/index.html. Updated January 25, 2021. Accessed April 22, 2021.

3. About HICPAC. Centers for Disease Control and Prevention website. https://www. cdc.gov/hicpac/about.html. Updated November 5, 2015. Accessed April 22, 2021.

4. Transmission-based precautions. Centers for Disease Control and Prevention website. https://www.cdc.gov/infectioncontrol/basics/transmission-based-precautions. html. Updated January 7, 2016. Accessed April 22, 2021.

5. Segal P. The evolution of isolation precautions. Infection Control Today website. https://www.infectioncontroltoday.com/view/evolution-isolation-precautions. Published March 19, 2018. Accessed April 22, 2021.

6. Hand hygiene recommendations. Centers for Disease Control and Prevention website. https://www.cdc.gov/coronavirus/2019-ncov/hcp/hand-hygiene.html. Updated May 17, 2020. Accessed April 22, 2021.
7. Isolation precautions. Centers for Disease Control and Prevention website. https:// www.cdc.gov/infectioncontrol/guidelines/isolation/index.html. Published 2007. Updated July 22, 2019. Accessed April 22, 2021.

8. Understanding the difference. Centers for Disease Control and Prevention website. https://www.cdc.gov/niosh/npptl/pdfs/understanddifferenceinfographic-508.pdf. Accessed April 22, 2021.

9. Implementing filtering facepiece respirator (FFR) reuse, including reuse after decontamination, when there are known shortages of N95 respirators. Centers for Disease Control and Prevention website. https://www.cdc.gov/coronavirus/2019ncov/hcp/ppe-strategy/decontamination-reuse-respirators.html. Updated October 19, 2020. Accessed April 22, 2021.

10. NIH study validates decontamination methods for re-use of N95 respirators. National Institutes of Health website. https://www.nih.gov/news-events/newsreleases/nih-study-validates-decontamination-methods-re-use-n95-respirators. Published April 15, 2020. Accessed April 22, 2021.

11. Fischer RJ, Morris DH, van Doremalen N, et al. Assessment of N95 respirator decontamination and re-use for SARS-CoV-2. medRxiv website. https://www. medrxiv.org/content/10.1101/2020.04.11.20062018v2. Published April 24, 2020. Accessed April 22, 2021.

12. Using personal protective equipment (PPE). Centers for Disease Control and Prevention website. https://www.cdc.gov/coronavirus/2019-ncov/hcp/using-ppe.html. Updated August 19, 2020. Accessed April 22, 2021.

13. Rutala WA, Weber DJ. Best practices for disinfection of noncritical environmental surfaces and equipment in healthcare facilities: a bundle approach. Am J Infect Control. 2019;47S:A96-A105.

14. Spaulding EH. Chemical disinfection of medical and surgical materials. In: Lawrence C, Block SS, eds. Disinfection, Sterilization, and Preservation. Lea \& Febiger; 1968:517-531.

15. Rutala WA, Weber DJ. Surface disinfection: treatment time (wipes and sprays) versus contact time (liquids). Infect Control Hosp Epidemiol. 2018;39:329-331.

16. Disinfection of healthcare equipment: guideline for disinfection and sterilization in healthcare facilities (2008) - concerns about implementing the Spaulding scheme. Centers for Disease Control and Prevention website. https://www.cdc.gov/ infectioncontrol/guidelines/disinfection/healthcare-equipment.html. Published 2008. Updated May 24, 2019. Accessed April 22, 2021.

17. West AM, Teska PJ, Oliver HF. There is no additional bactericidal efficacy of Environmental Protection Agency registered disinfectant towelettes after surface drying or beyond label contact time. Am J Infect Control. 2019;47:27-32.

18. Rutala WA, Weber DJ. Monitoring and improving the effectiveness of surface cleaning and disinfection. Am J Infect Control. 2016;44(5 suppl):e69-e76.

19. Strategies for Optimizing the Supply of Disposable Medical Gloves. Centers for Disease Control and Prevention website. https://www.cdc.gov/coronavirus/2019ncov/hcp/ppe-strategy/gloves.html. Updated December 23, 2020. Accessed April $22,2021$.

20. Rutala WA, Weber DJ. Selection of the ideal disinfectant. Infect Control Hosp Epidemiol. 2014;35:855-865.

21. Role of the environmental surfaces in disease transmission: "no touch" technologies reduce HAIs. Statewide Program for Infection Control and Epidemiology website. https://spice.unc.edu/wp-content/uploads/2017/05/Role-of-Env-Surfacesin-Disease-Transmission-Rutala.pdf. Accessed April 22, 2021.

22. Kramer A, Schwebke I, Kampf G. How long do nosocomial pathogens persist on inanimate surfaces? A systematic review. BMC Infect Dis. 2006;6:130.

23. How long will coronavirus survive on surfaces? Cleveland Clinic website. https:// health.clevelandclinic.org/how-long-will-coronavirus-survive-on-surfaces. Published August 5, 2020. Accessed April 22, 2021.

24. Davenport MS, Bruno MA, Iyer RS, et al. ACR statement on safe resumption of routine radiology care during the coronavirus disease 2019 (COVID-19) pandemic. J Am Coll Radiol. 2020;17:839-844.

25. Skali H, Murthy V, Paez D, et al. Information statement: Guidance and best practices for reestablishment of non-emergent care in nuclear cardiology laboratories during the coronavirus disease 2019 (COVID-19) pandemic: An information statement from ASNC, IAEA, and SNMMI. https://www.asnc.org/files/Skali_et_al2020-Journal_of_Nuclear_Cardiology\%20(1)Restart.pdf. Accessed May 20, 2021. 